\title{
暑熱環境における湿度感に関する基礎的実験 EXPERIMENTAL STUDY ON AIR HUMIDITY SENSATION IN HOT ENVIRONMENTS
}

\author{
松尾朋浩*, 窪田英樹**, 鎌田紀彦***, 若松伸司**** \\ Tomohiro MATSUO, Hideki KUBOTA, Norihiko KAMATA \\ and Shinji WAKAMATSU
}

\begin{abstract}
In order to examine the relationship between Air Humidity Sensation (AHS) and skin relative humidity, a series of experiments of three different conditions on Air Humidity Sensation was conducted with subjects of both sedentary and ergometer activity conditions in hot environment. Skin relative humidity was identified by applying measured mean skin temperature and sweat rate. For the experiment in which only AHS was asked, predicted mean skin temperature and sweat rate were applied. After analysis, it has been confirmed that the Air Humidity Sensation has a good correlation with the relative humidity of the air at the skin surface.
\end{abstract}

Keyword: humidity sensation, skin relative humidity, sweating, mean skin temperature, thermal environment, hot environment 湿度感、皮唐相対湿度、発汗、平均皮虍表面温度、温熱環境、暑熱環境

\section{1 はじめに}

温熱環境に関する研究は過去長い間、空調、生理学など様々な視点 により研究されてきた ${ }^{1.22}$ 。日本においてもこの研究は行われており、 欧米で作られた指標を取り入れる方法がその主流となっている。一方 で、日本の夏には『蒸し暑さ』のように湿度ぬきには語れない問題も 存在する。しかし、湿度の低い欧米で始まったこの分野の研究は、当 然のことながら研究の焦点が温冷感や快適感に当てられる場合がほと んどであり、湿度感生1について明確に述べた研究は少ない3 14)。

Berglund は湿度感(perceived ambient humidity by sedentary subjects)が 空気の露点温度(絶対湿度)の関数であるとし、空気の露点温度が同じ であればそのときの湿度感もほぼ一定の値を示すことを椅座時の被験 者実験の結果を用いて示している3）。しかし一方で、酒井らは「乾湿 感」が水蒸気圧、相対湿度とはほとんど相関は見られず、むしろ室気 温との関連が強いと述べている7)。また、小関・田辺ら ${ }^{14}$ も、同じ絶対 湿度でも室温によって「乾湿感」が異なる結果を得ている。

これらの実験は、結果的に「湿度感」が『やや湿っている』を超え る程度の実験条件で行われており、絶対湿度が比較的狭い範囲での実 験結果であることが「湿度感」が明確にされていない理由の 1 つとも 思われる。筆者らの研究でも、本論文で示すように水蒸気圧（絶対湿 度) が湿度感に強く関わる量の 1 つであることを示唆する結果が得ら れてる。しかし、着衣の影響、運動時に発汗量が増えた場合を考慮す
ると、湿度感が絶対湿度などの単一の環境要素のみで評価できるかど
うかは、疑問が残る。
一方、湿度感に類似した感覚に発汗による濡れ感がある。Berglund は perceived skin moisture（濡孔感）と夷測によって得られた濡れ率 (measured skin wetness) とが高い相関を示すと述べている3)。これは、 筆者らの研究において『発汗感』(汗をかいている程度を答えたもの) が濡れ率と高い相関を示すことと対応する。しかし、これは身体の状 態を評価したもので、空気の湿度という環境を「主観的」に評価する 『湿度感』とは、関係が深いものの別の感覚と考えられる既報、。

本研究では、湿度感と皮盧表面の相対湿度 $R H_{s k}$ (以下、皮虚相対湿 度)との関係を分析した結果について述べる。実験は、次の条件 “代 謝量 $=1 \& 2.8 \mathrm{met}$, 気流 $=0.1 \sim 1.8 \mathrm{~m} / \mathrm{s}$ 、相対湿度 $=50 \& 80 \%$ 、

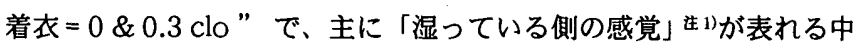
立温度より高い室温において実施した。

\section{2 実験方法・摡要}

本論文で扱う実験は次に示す 3 種類である(表 1)。

\section{実験 I：著衣 0.3clo、掎座の実験}

実験条件 a (1994 年 10 11 月): 室温 28、30、32、34 ${ }^{\circ} \mathrm{C} 、$ 相対湿 度 $80 \%$ 、気流 $0.1 、 0.3 、 0.6 、 1.2 、 1.8 \mathrm{~m} / \mathrm{s}$ の組合わせで、異なる 18 条件について夷験を行った。

\footnotetext{
* 室蘭工業大学大学院建設工学専攻 大学院生 $\cdot$ 工修

** 室蘭工業大学建設システム工学科 教授・工博

*** 室蘭工業大学建設システム工学科 助教授・工博

****国立環境研究所地域環境研究グループ大気保全研究チー 么 総合研究官・工博
}

Graduate Student, Division of Civil and Environmental Eng., Muroran Institute of Technology, M. Eng.

Prof., Dept. of Civil Eng. and Architecture, Muroran Institute of Technology, Dr. Eng.

Assoc. Prof., Dept. of Civil Eng. and Architecture, Muroran Institute of Technology, Dr. Eng.

Leader, Urban Air Quality Research Team, Regional Environmental Division, National Institute for Environmental Studies, Dr. Eng. 


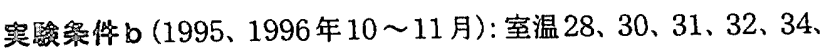
$36^{\circ} \mathrm{C}$ 、相対湿度 $50 \%$ 、気流 $0.1 、 0.3 、 0.6 、 1.2 、 1.8 \mathrm{~m} / \mathrm{s}$ の組合わ せで、異なる 16 条件について実験を行った。

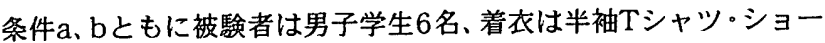
トバンツの約 0.3 cloである。被験者は中立温度 $\left(27^{\circ} \mathrm{C} 、 50 \%\right)$ 淮備 室に椅座で 30 分間過ごし、その後実験室へ移動し 30 分間予め設定さ れた気流を椅座で前方から全身に受ける。気流発生装置は吹出し開口 部 $150 \times 50 \mathrm{~cm}$ 、吹出し口から被験者の頭部までは約 $145 \mathrm{~cm}$ であり、 気流速度は無人時の椅座被験者位置における平均値を用いた。室温測 定／主観申告は準備室滞在 30 分後、実験開始 $0 、 3 、 10 、 20 、 30$ 分で ある。ただし、被験者の皮居表面温度などの生理量の測定は行ってい ない。環境測定にはアースマン乾湿計、グローブ温度計、超音波流速 計を使用した。

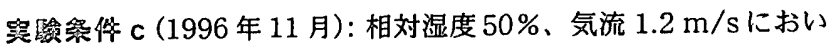
て室温 $33 、 36{ }^{\circ} \mathrm{C}$ の 2 条件について実験を行った。被験者は男子学生 3

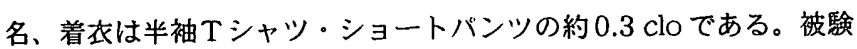
者は中立温度 $\left(27^{\circ} \mathrm{C} 、 50 \%\right)$ )準備室に椅座で 40 分間過ごし、その後実 䟻室へ移動し180分間予め設定された気流を椅座で前方から全身に受 ける(条件 $\mathrm{a} 、 \mathrm{~b}$ 参照)。この間、準備室・実䟻室を通して5 分間隔で皮

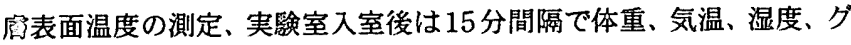
ローブ温度を記録する。被験者の主観申告は、実験室 60、120、180 分である。皮膚表面温度・気温・グローブ温度の測定にはサーミスタ 温度計（タカラ $\mathrm{K} 722$ /センサー直径 $1 \mathrm{~mm}$ )、体重測定は精密体重計 (A\&D AD - 6205/最小表示 $20 \mathrm{~g}$ )、湿度の測定はアースマン乾湿計 を使用した。なお、皮庐表面温度の測定、平均皮館表面温度(以下、平 均皮温)の算出にはHardy-DuBois の 7 点法(7 部位で各 1 点測定) ${ }^{22,23)}$ 用いた。

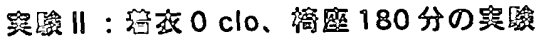

鼠駩绿仵 (1998年 $10 \sim 11$ 月): 室温 $30 、 33 、 36^{\circ} \mathrm{C}$ 、相対湿度 50 、 $70 \%$ (室温 $30^{\circ} \mathrm{C}$ のみ $80 \%$ )、気流 $0.1 \mathrm{~m} / \mathrm{s}$ 合計 6 条件である。

被験者は男子学生6名、着衣はトランクスのみの約 0 cloである。被 鈳者は、中立温度 $\left(27.5^{\circ} \mathrm{C} 、 55 \%\right)$ の準備室に 1 時間滞在し、その後実 鏂室へ移動して 180 分間椅座で過ごす。この間、淮備室・実駼室を通 して 5 分間隄で皮呞表面温度の測定、実験室入室後は 15 分間隔で体 重、気温、湿度、グローブ温度、被験者の主観申告を記録する。皮居 表面温度・気温・グローブ温度の測定にはサーミス夕温度計（タカラ $\mathrm{K} 722$ /センサー直径 $1 \mathrm{~mm}$ )、体重測定は電子天科 (A\&D HP - 100 /最小表示 $1 \mathrm{~g}$ )、湿度の測定はアースマン乾湿計を使用した。なお、 皮雇表面温度の測定、平均皮温の算出にはHardy-DuBois $の 7$ 点法を用 いた。

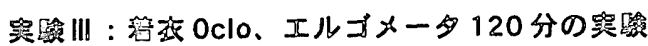

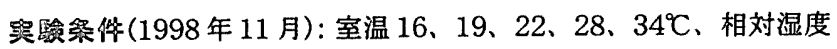
$50 \%$ 、気流 $0.1 \mathrm{~m} / \mathrm{s}$ 合計 5 条件である。

被験者は男子学生 4名、着衣はトランクスのみの約 0 cloである。被 䟻者は中立条件 $\left(27.5^{\circ} \mathrm{C} 、 55 \%\right)$ の準備室に 30 分間滞在し、その後実鈳 室へ移動して『1分間の立位 : 体重測定』と『9分間のエルゴメー夕運 動』を 1 サイクルとする 10 分周期の作業 (平均代謝量 2.8 met、外部 機械仕事率0.16）を120分間続ける。自転車エルゴメータ運動時の代 謝量を 3 metに設定し、この代謝を維持するようにエルゴメータの負 荷を $28.5 \mathrm{~W} / \mathrm{m}^{2}$ に調整した。この間、準備室・実鈳室を通して5分間
隔で皮局表面温度の測定、実験室入室後は 10 分間隔で体重、気温、湿 度、グローブ温度、被験者の主観申告を記録する。エルゴメータは キャットアイ製(EC - 1600) を使用。その他の機器は実験 II と同様 で、皮府表面温度・気温・グロープ温度の測定にはサーミスタ温度計 (タカラK722/センサー直径 $1 \mathrm{~mm}$ )、体重測定は電子天秤 (A\&D HP - 100 /最小表示 $1 \mathrm{~g}$ )、湿度の測定はアースマン乾湿計を使用した。 皮㕣表面温度の測定、平均皮温の算出にはHardy-DuBoisの7点法を用 いた。

なお、湿度感(Air Humidity Sensation $=$ AHS)の申告には、次の尺度 を用いた。 $+3=$ 非常に湿っている、 $+2=$ 湿っている, $+1=$ やや湿つ ている, $0=$ どちらでもない, $-1=$ やや乾燥している, $-2=$ 乾燥して いる、 $-3=$ 非常に乾燥している

表1 実験条件

\begin{tabular}{|c|c|c|c|c|c|c|c|c|c|c|c|}
\hline \multirow[b]{2}{*}{ 流邀 $[\mathrm{m} / \mathrm{s}]$} & \multicolumn{11}{|c|}{ 気温 $\left[{ }^{\circ} \mathrm{C}\right]$} \\
\hline & 16 & & & & 28 & 30 & 31 & 32 & 33 & 34 & 36 \\
\hline 0.1 & 圈实 & 国整 & 凅 & 国整 & $O \triangle$ & $\triangle \triangle \triangle \triangle$ & 0 & $\Delta$ & (1) 4 & $\mathrm{O} \triangle$ & 1. \\
\hline 0.3 & & & & & $\Delta$ & $O \triangle$ & & $O \triangle$ & & $O \triangle$ & \\
\hline 0.6 & & & & & $\Delta$ & $O \triangle$ & & $O \triangle$ & & $O \triangle$ & \\
\hline 1.2 & & & & & & $O \triangle$ & & $O \triangle$ & $\diamond$ & $O \triangle$ & $\diamond$ \\
\hline 1.8 & & & & & & $\Delta$ & & $\triangle$ & & $O \triangle$ & \\
\hline
\end{tabular}

(11): RH50\% 0clo、曲: RH70\% Oclo(気温 $30^{\circ} \mathrm{C}$ のみ RH80\%)

$\mathrm{O}: \mathrm{RH} 50 \%$ 0.3clo, $\triangle:$ RH80\% $0.3 \mathrm{clo}$

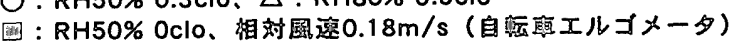

$\diamond:$ RH50\% $0.3 \mathrm{clo} 1.2 \mathrm{~m} / \mathrm{s}$

表2 被跧者(男性)

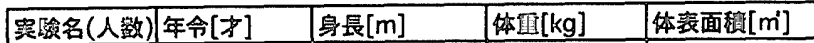
\begin{tabular}{|l|l|l|l|l|}
\hline 实政 I a (6) & $22.3( \pm 0.4)$ & $1.71( \pm 0.04)$ & $63.5( \pm 5.0)$ & $1.74( \pm 0.06)$ \\
\hline
\end{tabular}

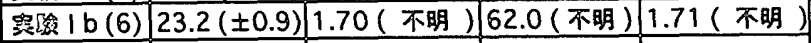
\begin{tabular}{|l|l|l|l|l|}
\hline 突涂 I c (3) & $21.8( \pm 0.6)$ & $1.75( \pm 0.05)$ & $65.7( \pm 6.0)$ & $1.79( \pm 0.09)$ \\
\hline
\end{tabular} \begin{tabular}{|l|l|l|l|l|l|}
\hline 实拨 II (6) & $21.8( \pm 0.4)$ & $1.74( \pm 0.03)$ & $62.1( \pm 2.9)$ & $1.74( \pm 0.05)$ \\
\hline
\end{tabular}

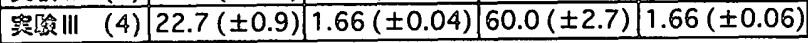

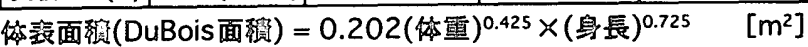
体筌 $[\mathrm{kg}]$ 、或 $[\mathrm{m}]$

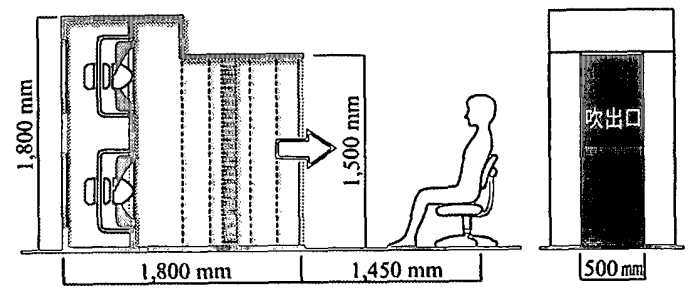

図1気流発生装置

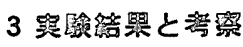

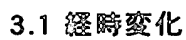

図 2 に平均皮温と湿度感の経時変化を示す（図中の数値は ${ }^{\circ} \mathrm{C}-\%$ )。 今回の実験条件のような暑熱睘境においては、30分から1時間程度で ほほ定常とみなすことのでさる状態に落ち着くことがわかる。特に湿 度感は、実験開始後ほとんど一定の値を示していることがわかる。こ のことから実験 I a,bに関しては、30分経過した実験終了時の「湿度 感」の値を定常值とみなしても大差ないと考えられる。実虽 I C、I， IIIに関しては、実験開始後 60 分以降の平均値を定常値として使用す る。 

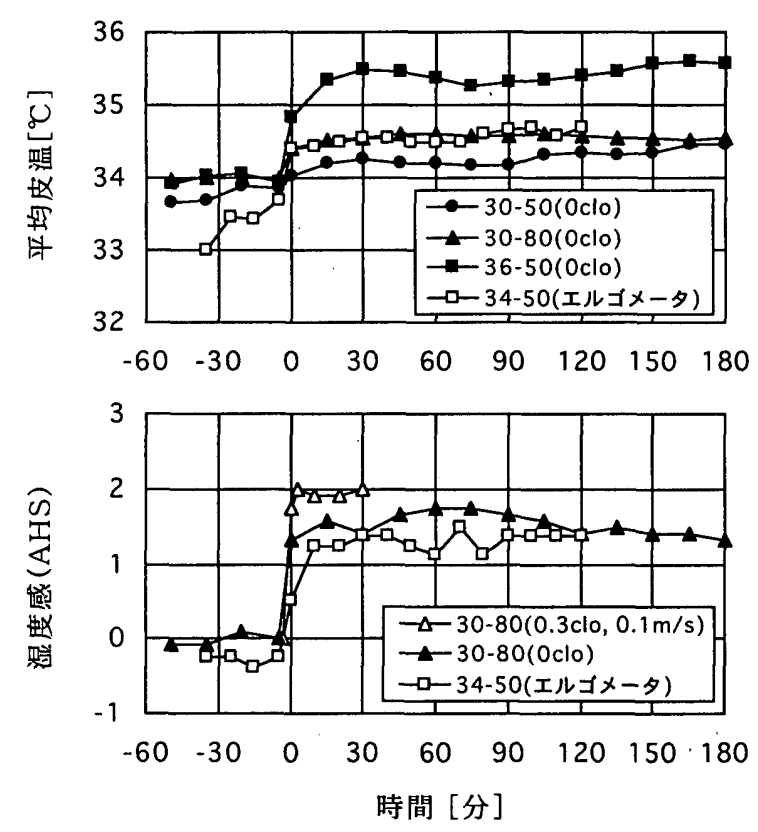

図2平均皮温と湿度感の経時変化

\section{2 皮虔相対湿度}

皮膚相対湿度 $R H_{\text {sk }}$ は皮虚に接する空気の水蒸気圧 $p_{s k s f}$ 之平均皮温 における飽和水蒸気圧 $p_{\mathrm{sk}}$ の関係によって次式で定義される ${ }^{15.16) 。 ~}$ $R H_{s k}=p_{s k s f} / p_{s k}$

上式から、次に示す既存の皮䖉相対湿度の関係式 ${ }^{15)}$ が導かれる。詳 細はAPPENDIX II を参照。

$R H_{s k}=W+(1-W) p_{a} / p_{s k}$

ここで、濡れ率 $W$ は皮膚表面からの蒸発密度(拡散蒸散と発汗) $q_{\mathrm{wsk}}$ と最大蒸発密度 $q_{w \max }$ の関係として次式で定義する。

$$
\begin{aligned}
W & =q_{w s k} / q_{w \max } \\
& =q_{\mathrm{w} s k} /\left\{k_{\max }\left(p_{s k}-p_{a}\right) / k_{L}\right\}
\end{aligned}
$$

\section{a）皮膚表面からの蒸発密度 $q_{w s k}$ の算出方法}

実験結果を用いて $q_{\text {wsk }}$ を算出する方法を示す。体重隇少には、呼吸 と体表からの水分流出(蒸発と滴下)、呼吸のガス交換による体重減少、 体表と着衣への水分蓄積、が関与するが、本論文では呼吸のカス交換 による体重減少、体表と着衣への水分蓄積の影響は無視した。つまり、 皮層表面からの蒸発密度(搗散蒸散と発汗) $q_{\mathrm{ws} k}$ は体重減少密度 $q_{\mathrm{w} b}$ か ら呼吸による蒸発密度 $q_{\text {wres }}$ を差引くことで次式で推定する。

$$
q_{\mathrm{u}: \mathrm{sk}}=q_{\mathrm{w} b \mathrm{~b}}-q_{\mathrm{ures}} \quad \mathrm{g} /\left(\mathrm{h} \cdot \mathrm{m}^{2}\right)
$$

ここで、呼吸による体重減少には次の関係式を適用したり。 $q_{\text {wres }}=k_{\text {Lres }}\left(p_{e x}-p_{a}\right) / k_{L}=0.0173 q_{M}\left(5.87-p_{a}\right) / k_{L} \quad \mathrm{~g} /\left(\mathrm{h} \cdot \mathrm{m}^{2}\right)(6)$

\section{b) 平均皮温と皮虔相対湿度の理論的予測値の検証(実験結果との比较)}

実験 I $\mathrm{a} 、 \mathrm{~b} て ゙ は$ 平均皮温などの生理量は測定していない。このとき の皮膚相対湿度 $R H_{s k}$ は、APPENDIX I に示す予測式 ${ }^{17 \sim 19.211}$ (式(A4)、 (A6))を用いて算定した。図3、4 は、この予測式の適合性を実験 I C、 II、IIIの実測值と比較することにより検証したものである。同図は、 予測值が実測値を十分反映することを示している。

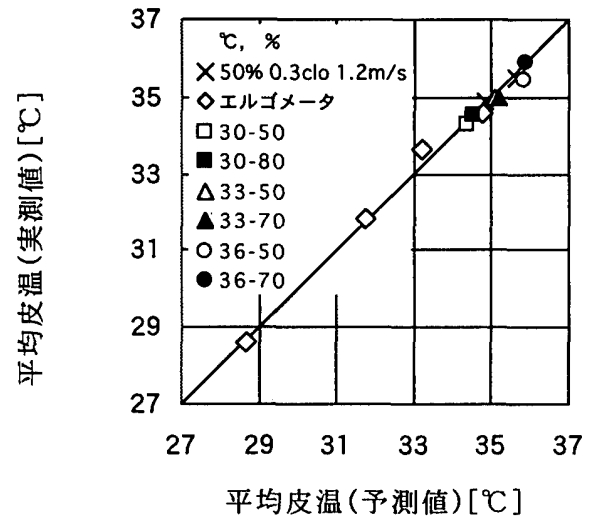

図3 平均皮温 $t_{\mathrm{sk}}$ :予測値と実測值の比較

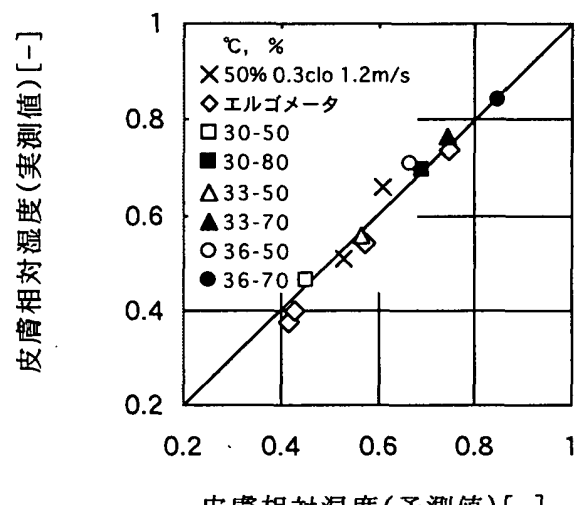

図4 皮膚相対湿度 $R H_{s k}$ : 予測値と実測値の比較

\section{3 湿度感と皮虔相対湿度 $R H_{s k}$}

図 5 は、湿度感と皮層相対湿度 $R H_{s k}$ の関係を示したものである。実 験 I c、II、IIIについては、実測した平均皮温 $t_{s k}$ と蒸発量を適用した 濡㧈率 $W$ を用い、実験 $\mathrm{I} \mathrm{a} 、 \mathrm{~b}$ の平均皮温 $t_{\mathrm{sk}}$ と濡れ率 $w$ は、上記の ように予測值を用いた(APPENDIX I、式(A4)、式(A6)参照)。

湿度感と皮唐相対湿度 $R H_{s k}$ の相関が高いことがわかる。特に、裸体 時の実験 II、III（図中の曰、○、ム）はほぼ一直線上に並んでいる。 このとき、湿度感（AHS : Air Humidity Sensation）は皮膚相対湿度

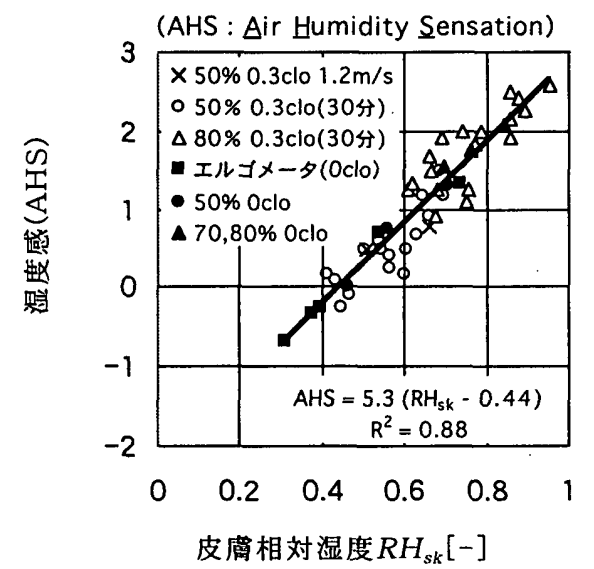

図5 皮虚相対湿度 $R H_{s k}$ と湿度感の関係 
$R H_{s k}$ の関数として次式で表わされる。

$\mathrm{AHS}=5.3\left(R H_{\text {sk }}-0.44\right)$

ND (7)

上の関係式より、湿度感が中立の「(0)どちらでもない」のときの皮 危相対湿度 $R H_{s k}$ は $44 \% 、 「(+3)$ 非常に湿っている」は皮虑相対湿度が ほほ $100 \%$ の飽和状態に対応することがわかる。

図6 は皮扂相対湿度と湿度感の関係について、本研究の実験結果と 既存の研究結果 ${ }^{13,14,24)}$ を比較したものである。既存の研究については、 皮廊相対湿度を実験条件を基に平均皮温予測式(式(A4))、皮局表面の 濡机率(式(A6))を用いて推測した。また、既存の研究の「乾湿感」は 湿度感と同じ意哧とみなして本研究の尺度に変換して統一した。概ね 良い関係を示しており、湿度感の評価に皮虑相対湿度が有効であると いえる。なお、これらの実験は、伊藤ら ${ }^{13}$ は $8 \sim 9$ 月、小関・田辺ら 14)は9〜10月に行われた実験である。

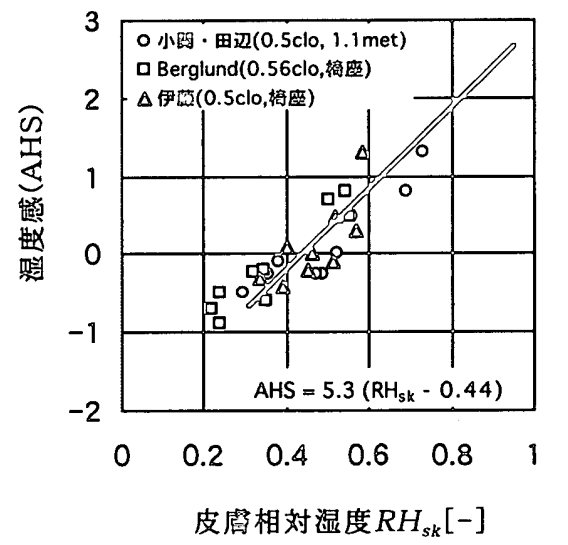

図6 皮扂相対湿度 $R H_{s k}$ と湿度感の関係 ${ }^{13,14,24)}$ （既存の結果との比較）

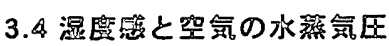

図 7 に湿度感と空気の水蒸気圧 $p_{a}$ の関係を示す。同図から、湿度 感が空気の水蒸気圧と高い相関を有していることがわかる。これは、 既存 ${ }^{3)} 「$ 湿度感が空気の水蒸気圧(絶対湿度)の影彺を受ける」結果と 矛盾しない。しかし、図 5 との大きな違いは、運動時(エルゴメータ) と椅座時(いずれも裸体)の結果が異なった傾向を示しており、同一直 線上にないことである。運動時の方が、同じ水蒸気圧でも湿度感が高 くなっている。これは運動時の発汗量が椅座時より多いことが原因と

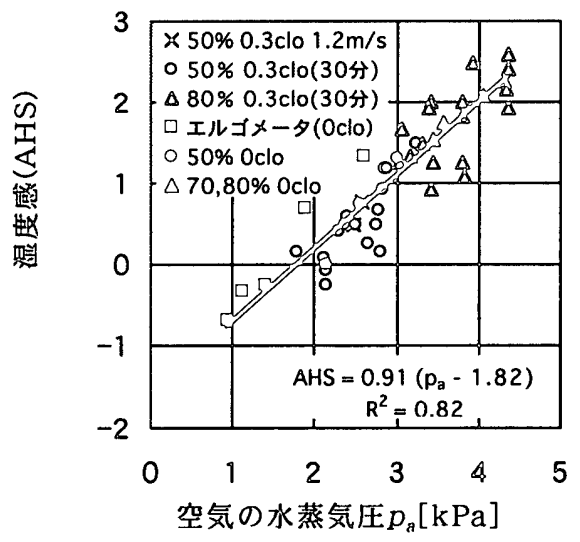

図7 空気の水蒸気圧と湿度感の関係
考えられる。この考えが正しいとすると、発汗量は全身温感と密接に 係わっているので既存の研究7.14)の「湿度感が気温の影琽を受ける」こ とになり、また、気流・着衣が環境への水蒸気拡散に影響することか ら、同じ水蒸気圧の環境の下でも湿度感が異なることが予想される。 着衣の影嵒については、今回の実験では明確には表れていないが、 これは着衣量 $0.3 \mathrm{clo}$ と $0 \mathrm{clo}$ と、その差が小さいためと考元られる。

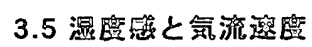

気流速度の影瑤を調べたのが図 8、9である。これらは、着衣時 0.3 cloの実験結果を流速ごとに表したものである。図中の直線は、流速別 の回帰直線の傾きに有意差が認められなかったため(有意水準5\%)、傾 きが同じとした場合の流速別の直線である。

まず、図8は湿度感を $R H_{s k}$ に対して示したものである。流速の一番 大きい $1.8 \mathrm{~m} / \mathrm{s}$ が一番下、次いで $1.2 \mathrm{~m} / \mathrm{s}$ が辛うじて下から 2 番目と はなるが、そ扎以外は明確ではない。図8についての共分散分析の結 果、湿度感と $R H_{s k}$ の関係においては、各流速間に有意な差は認められ なかった(有意水準 $5 \%$ )。つまり、皮虎相対湿度が湿度感を良く表現し ていると言える。

一方、湿度感を周囲空気の水蒸気圧 $p_{n}$ に対して示した図9では、直 線は上から順に0.1、0.3、0.6、1.2、1.8 m/s と流速が大きいほど湿 度感が小さくなる傾向が明確に読み取れる。共分散分析の結果、湿度 感と周囲空気の水蒸気圧の関係では流速間に有意な差が認められた(有

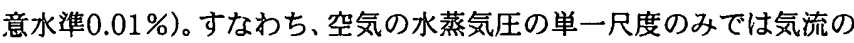
影㓡を含めた湿度感を評価できないことがわかる。

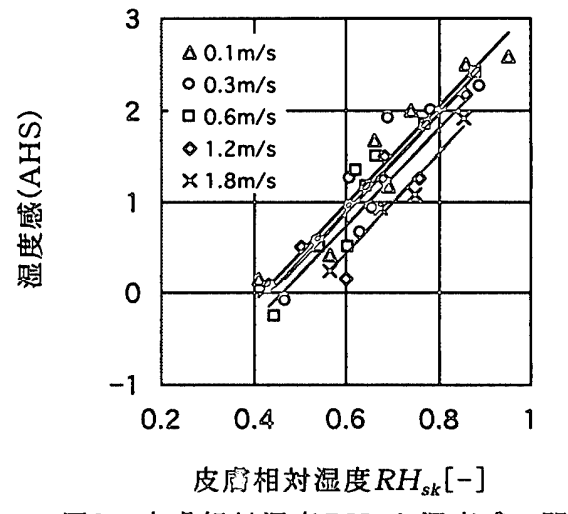

図8 皮府相対湿度 $R H_{s k}$ と湿度感の関俰

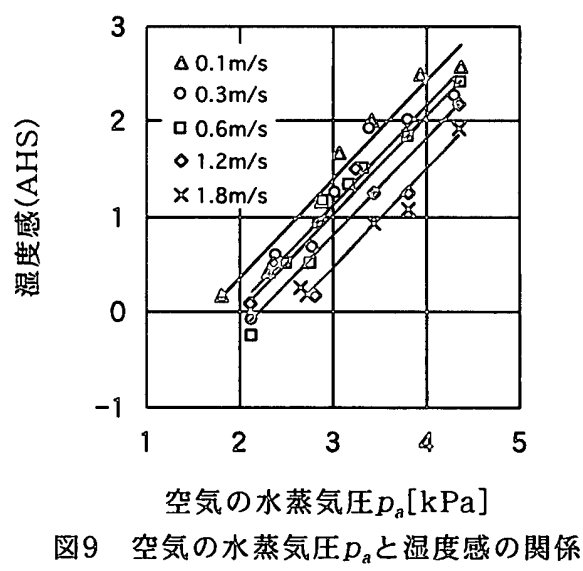




\section{6 湿度感に関する考察}

以上のことから、「湿っている側」の湿度感に関しては、代謝と気 温・湿度・気流などの影響を総合的に反映した皮唐相対湿度がその良 い指標であることが、ほぼ確認されたと言うことができよう。

これは、湿度感が皮膚表面の角質層の含水率と関わることを示唆し ている。すなわち、一般に、木材・紙などの材質の含湿率は、それに 接する空気の相対湿度の関数であることが知られているが、角質層も 同様に皮層表面の空気の相対湿度の影響を強く受けると考えることが できる。つまり、日常生活で感じる湿度感は、「室内環境の空気の湿 度」そのものに対してではなく、「皮膚表面に接する空気の湿度」に対 する感覚であることを示している。

一方、呼吸に倸わる粘膜からの蒸発には周囲空気(吸気)の水蒸気圧 が関係しているが、外部環境の人体に対する風速とは無関係である。 仮に、呼吸器系の粘膜が湿度感に卓越した影響を有するとすれば、呼 吸器を通過する気流の影響は受けても、人体周囲の風速の影響は受け ないことになる。しかし図9に示されている周囲空気の水蒸気圧(=吸 気の水蒸気仕)との関係では、湿度感は明らかに環境側の風速の影響を 受けており、従って、鼻腔・咽頭・気管等の粘膜は「湿っている側の 感覚」には大きな影響を有するとは考え難い。

\section{4 結論}

湿度感(AHS)が、皮膚相対湿度 $R H_{s k}$ の関数で表現できることを、3 種類の実験結果（実験条件：代謝量 $=1 \& 2.8 \mathrm{met}$, 気流 $=0.1 \sim 1.8$ $\mathrm{m} / \mathrm{s}$ 、相対湿度 $=50 \& 80 \%$ 、着衣 $=0 \& 0.3 \mathrm{clo}$ ）を基にして示した。 その結果、湿度感(AHS)を皮䖉相対湿度 $R H_{s k}$ の関数として表わす次式 を得た。

$$
\text { AHS }=5.3\left(R H_{s k}-0.44\right)
$$

ここで、AHS : 湿度感 $(+3=$ 非常に湿っている, $+2=$ 湿ってい る, $+1=$ やや湿っている, $0=$ どちらでもない, $-1=$ やや乾燥し ている, $-2=$ 乾燥している,$-3=$ 非常に乾燥している)

ただし、上式の適用範囲は $0.4<R H_{s k} \leqq 1$ 、全身温感が中立より暑 い側とする。この結果は、人間が感じる湿度感が「皮盧表面に接して いる空気の湿度」に対する感覚であり、全身温感と発汗の增加の影響 を受け、同時に着衣と気流の影響も受けることを示している。湿度感 が中立時の皮層相対湿度 $R H_{s k}$ は $44 \%$ 、「非常に湿っている」ではほぼ 100\%の飽和状態であった。

謝辞 データの分析や実験に協力いただいた後藤友邦、竹内崇、遠藤 裕輔、岩本昌也、浜田博之、秋山竜也、伊藤亚希彦、穂蒱高志、宮下 雅之、森原崇、赤上ゆきの、山村由香、三井雪恵、小笠原美詠、94、95、 96 年署熱実験に被験者として参加していただいた諸氏に感謝します。 なお、この研究は、国立環境研究所を中心とする地球環境研究プロ ジェクトの一貫として進められた「家庭等における二酸化炭素排出抑 制システムに関する研究 (平成 3-5 年)」「地球温暖化防止对策技術の 総合評価に関する研究 (平成6-8年)」の研究の過程で発想されたもの であり関係各位に感謝いたします。

注 1) 本研究では、湿度感を「(+)湿っている側〜(-)乾燥している側」 で表現する。類似する用語に乾湿感「(+)乾燥している側〜(-)湿っ ている側 ${ }^{6 \sim 14)}$ がある。両者は尺度が逆転している以外は、同じ意 味と著者らは考えている。
本論文の内容の一部は下記の機会に報告した。

a) 松尾朋浩、㴶田英樹、竹内崇、堀井崇司、鎌田紀彦 : 夏期室内環境 の評価(2)空気の湿度感に関する一考察、日本建築学会大会学術講演 梗概集(関東 D2)、No.41179、373-374、1997.9.

b) 松尾朋浩、嶉田英樹、朝比奈亮、浜田博之、山越健弘 : 椅座時の温 熱性発汗と人体平均皮層表面温度に関する基礎実験、空気調和・衛 生工学北海道支部、77-80、1999.3.

c) 松尾朋浩、沙田英樹、朝比奈亮、浜田博之、山越健弘 : 椅座時の温 熱性発汗・人体平均皮温・湿度感に関する基礎実験、日本建築学会 大会学術講演梗概集(中国 D)、No.41164、327-328、1999.9.

\section{参考文献}

1) Fanger, P. O.,; Thermal Comfort, McGraw-Hill, New York, 1972.

2) Gagge, A. P., Stolwijk, J. A., Nishi, Y., : An effective temperature scale based on a simple model of human physiological regulatory response, ASHRAE Trans., 77(1), 247-262, 1971

3) Berglund, L. G., : Comfort and Humidity, AHRAE Journal, August, 35-41, 1998.

4) Gagge, A. P., Fobelets, A. P., Berglund, L. G., : A standard predictive index of human response to the thermal environment, ASHRAE Trans., 92(2B), 709-731, 1986.

5) Gonzalez, R. R., Berglund, L. G., Gagge, A. P. : Indices of thermoregulatory strain for moderate exercise in the heat, Journal of Applied Physiology: Respiration Environment Exercise Physiology, 44(6), 889-899, 1978.

6) 岩本静男、石井昭夫、片山忠久、堤純一郎、酒井英二、籠田真一郎 : 温熱環境における低湿冷房の影響に関する研究 (その1) 被験者によ る申告実験の概要、日本建築学会大会学術講演梗概集 (北陸 D)、 4504、1007-1008、1992.

7) 酒井英二、石井昭夫、片山忠久、堤純一郎、岩本静男、籠田真一郎 : 温熱環境における低湿冷房の影響に関する研究 (その2) 被験者によ る申告実験の概要、日本建築学会大会学術講演梗概集( 北陸 D)、 4505、1009-1010、 1992.

8) 酒井英二、石井昭夫、岩本静男、片山忠久、堤純一郎 : 冷房環境に おける温熱感覚申告 (その1) 湿度の影響、日本建築学会大会学術講 演梗概集(関東 D)、No.4672、1343-1344、1993.

9) 石井昭夫、岩本静男、酒井英二、片山忠久、堤純一郎 : 冷房環境に おける温熱感覚申告 (その2) 温熱指標による評価、日本建築学会大 会学術講演梗概集(関東 D)、No.4673、1345-1346、1993.

10) 姚鳳軍、石井昭夫、岩本静男、山下盛久、酒井英二 : 温熱感覚に 及ほす湿度の影響に関する研究 (その 1 ) 通常エアコンと湿度制御型 エアコンの比較実験、日本建築学会大会学術講演梗概集 (東北 D)、 No.4355、709-710、1991.

11) 酒井英二、石井昭夫、岩本静男、片山忠久、塩月義隆、堤純一郎、 山下盛久、姚鳳軍 : 温熱感覚に及ぼす湿度の影響に関する研究（そ の2) 人工気候室における被験者実験、日本建築学会大会学術講演梗 概集(東北 D)、No.4356、711-712、1991.

12) 深井一夫、伊藤宏、佐々木真希 : 温熱的中立付近の環境における 湿度の快適限界に関する実験的検討 その1 冬期被験者実験による 低湿側の検討、日本建築学会大会学術講演梗概集(関東 D)、4674、 1347-1348、1993. 
13) 伊藤宏、樑井一夫、佐々木真希 : 温熱的中立付近の環境における 湿度の快適限界に関する実験的検討 その2 夏季被験者実鈳による 高湿側の検討、日本建築学会大会学術講演梗概集(関東 D)、4675、 1349-1350、1993.

14) 小関敬子、田辺新一、今村寿子、鈴木孝佳 : オフィスにおける湿 度が熱的纼適性に与える影餐 その1 オフィス環境試験室における 被験者実験結果、空気調和・衛生工学会学術講演論文集(熊本)、G5、433-436、1994.10.

15) Berglund, L. G., Cunningham, and D. J.: Parameters of Human Discomfort in Warm Environments, ASHRAE Trans., Vol.92, part 2B, 732-746, 1986.

16) Mole, R. H.: The relative humidity of the skin, Journal of Physiology, 107, 399-411, and 1948.

17) 窪田英樹、松尾朋浩、伊地知健、鎆田紀彦、若松伸司 : 温熱性発 汗特性を考感した椅座時の平均皮虑表面温度の予測、日本建築学会 計画系論文集、No.532、2000.6.

18) Kubota, H., Ijichi, T., Kamata, N., Mean skin temperature as an index of human response to the thermal environment, Proceedings of the 7th International Conference on Indoor Air Quality and Climate, 1996.7, Nagoya, JAPAN, 221-226.

19) 真不学、䆶田英樹、山畸大史、松尾朋浩、竹内崇 : 㞄動時の発汗 特性と平均皮豦温予測モテル、空気調和・衛生工学会北海道支部、 195-198、1998.3.

20) ASHRAE HANDBOOK FUNDAMENTALS, 1997.

21) 松尾朋浩、涳田英樹、真木学、伊地知健、鑂田紀彦、若松伸司：運 動時の温熱性発汗と平均皮局表面温度の予測、日本建築学会計画系 論文焦、No.526、107-113、1999.12.

22) Hardy, J. D., DuBois, E. F. : The technic of measuring radiation and convection, Journal of Nutrition, Vol.15, No.5, 461-475, 1938.

23) Mitchell, D., Wyndham, C. H. : Comparison of weighting formulas for calculating mean skin temperature, Journal of Applied Physiology, Vol.26, No.5, 616-622, 1969.5 .

24) Berglund, L. G., Cain, W. S. : Perceived air quality and the thermal environment, The Human Equation: Health and Comfort, Proceedings of ASHRAE/SOEH Conferece IAQ '89 Atlanta: ASHRAE, 93-99, 1989.

25) McCllough, E. A., Jones, B. W., Tamura, T., A data base for determining the evaporative resistance of clothing, AHRAE Trans., Vol. 95(2), pp.316328,1989

26) Winslow, C. -E., Gagge, A. p., Herrington, B. P., The influence of air movement upon heat loss from the clothed human body, Journal of Physiology, 127, pp.505-518, 1939.

27) Nishi, Y., Gagge, A. P., Moisture permeation of clothing - a factor governing thermal equilibrium and comfort, AHRAE Trans., Vol.76, Part1, pp.137145,1970

28) Oohori, T., Berglund, L. G., Gagge, A. P., Comparison of current twoparameters indices of vapor permeation of clothing - as factors governing thermal equilibrium and human comfofrt, AHRAE Trans., Vol.91, Part2A, pp.85-101, 1984.

29) Winslow, C. -E. A., Herrington, L. P., Gagge, A. P., Physiological reaction of the human body to varying environmental temperature, The American Journal of Physiology, Vol.120, No.1, pp.1-22, 1937.
APPENDIX 1 :

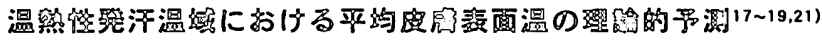

人体と環境との間の熱平衡式は、汗が全て体の表面で蒸発する場合、 次式のように表される。

$q_{M}(1-\eta)=q_{\text {Sres }}+q_{\text {Lres }}+q_{d l f}+q_{s w e}+q_{s w t}+q_{r}+q_{c} \quad \mathrm{~W} / \mathrm{m}^{2} \quad$ (A1)

この熱平衡式において、平均皮温を含むのは $q_{d I f} 、 q_{s w t}, q_{r} 、 q_{c}$ の4 項である。温熱性発汗 $q_{\text {swt }}$ に対しては次式を適用し、

$q_{s w t}=k_{s w t}\left(t_{s k}-t_{s k s w}\right)$

$\mathrm{W} / \mathrm{m}^{2} \quad(\mathrm{~A} 2)^{211}$

飽和水蒸気圧 $P_{s k}$ を平均皮温 $t_{s k}$ の一次式で近似する。すなわち、

$p_{s k} \fallingdotseq a_{s k} t_{s k}+b_{s k}$

$\mathrm{kPa}$ (A3)

これらの式(A2)，(A3)を適用すると、上記の 4 項 $q_{d i r} q_{s w t} 、 q_{r} 、 q_{c}$ は 全て平均皮温 $t_{s k}$ の一次式で表されることになり、平均皮温が上記の熱 平衡式(A1)から次のように得られる。

$$
\begin{aligned}
t_{s k}=\left[q_{M}(1-\eta)-\right. & \left\{q_{\text {Sres }}+q_{L r e s}+k_{\text {dff }}\left(b_{s k}-p_{a}\right)\right. \\
& +q_{s w e}\left(1-k_{\text {dif }} / k_{\max }\right) \\
& \left.\left.-k_{\text {swt }}\left(1-k_{\text {dif }} / k_{\max }\right) t_{s k s w}-k_{r c} t_{\mathrm{o}}\right\}\right]
\end{aligned}
$$

$/\left[a_{s k} k_{d i f}+k_{s w t}\left(1-k_{d f f} / k_{\max }\right)+k_{r c}\right] \quad\left(t_{s k s w} \leqq t_{s k} \leqq 36\right){ }^{\circ} \mathrm{C}$ (A4)

この結果を利用して、発汗による濡れ率は次式のように表される。 $w_{s w}=q_{s w} / q_{\max }$

$=\left\{k_{s w t}\left(t_{s k}-t_{s k s w}\right)+q_{s w e}\right\} /\left\{k_{\max }\left(p_{s k}-p_{a}\right)\right\}$

ND (A5)

一方、皮廟表面の濡れ率 $W$ は次式のように表わされる。 $W=W_{\text {dif }}+W_{s w}=\left(q_{d l f}+q_{s w}\right) / q_{\max }$

$=\left(1-W_{s w}\right) k_{d i f} / k_{\max }+w_{s w}$

ND (A6)

$k_{\max }=1 /\left(R_{\text {cle }}+R_{\text {se }}\right)$

$=1 /\left\{0.155 I_{c l} /\left(i_{c l} \cdot L R\right)+1 /\left(L R \cdot h_{c} \cdot f_{c l}\right)\right\} \quad \mathrm{W} /\left(\mathrm{m}^{2} \cdot \mathrm{kPa}\right)(\mathrm{A} 7)^{27,28)}$

式 (A4)、(A5)の計算には、下記の特性を適用した ${ }^{1)}$ 、

$q_{\text {Sres }}=k_{\text {sres }}\left(t_{e x}-t_{a}\right)=0.0014 q_{M}\left(34.0-t_{a}\right) \quad \mathrm{W} / \mathrm{m}^{2} \quad$ (A8) ${ }^{1)}$

$q_{\text {Lres }}=k_{\text {Lres }}\left(p_{\text {ex }}-p_{a}\right)=0.0173 q_{M}\left(5.87-p_{a}\right) \quad \mathrm{W} / \mathrm{m}^{2} \quad(\mathrm{~A} 9)^{1)}$

$k_{\text {dif }}=1 /\left(R_{\text {dif }}+R_{\text {cle }}+R_{\text {se }}\right)$

$=1 /\left\{0.328+0.155 I_{c l} /\left(i_{c l} \cdot L R\right)+1 /\left(L R \cdot h_{c} \cdot f_{c}\right)\right\} \mathrm{W} /\left(\mathrm{m}^{2} \cdot \mathrm{kPa}\right)(\mathrm{A} 10)^{1.27 .28)}$ $i_{c l}=0.34$

$\mathrm{ND} \quad(\mathrm{A} 11)^{20,25)}$

$h_{c}=12.1 v^{0.5}$

$\mathrm{W} /\left(\mathrm{m}^{2} \cdot \mathrm{K}\right) \quad(\mathrm{A} 12)^{26)}$

$a_{s k}=0.270 \mathrm{kPa} / \mathrm{K} 、 b_{s k}=-3.834 \mathrm{kPa}$

$q_{\text {swe }}=0.42\left\{q_{M}(1-\eta)-58.14\right\}$

$\mathrm{W} / \mathrm{m}^{2} \quad(\mathrm{~A} 14)^{1)}$

$k_{s w t}=28\left(t_{s k} \geqq t_{s k s w}\right) 、 \quad k_{s w t}=0\left(t_{s k}<t_{s k s w}\right) \quad \mathrm{W} /\left(\mathrm{m}^{2} \cdot \mathrm{K}\right) \quad(\mathrm{A} 15)^{21)}$

$k_{\text {dif }} / k_{\max }=\left\{0.155 I_{c l} /\left(i_{c l} \cdot L R\right)+1 /\left(L R \cdot h_{c} \cdot f_{c}\right)\right\}$

$$
/\left\{0.328+0.155 I_{c l} /\left(i_{c l} \cdot L R\right)+1 /\left(L R \cdot h_{c} \cdot f_{c l}\right)\right\} \text { ND (A16) }
$$

$q_{r c}=k_{r c}\left(t_{s k}-t_{\mathrm{op}}\right)$

$\mathrm{W} / \mathrm{m}^{2} \quad$ (A17)

$k_{r c}=1 /\left\{0.155 I_{c l}+1 /\left(h \cdot f_{c l}\right)\right\}$

$\mathrm{W} /\left(\mathrm{m}^{2} \cdot \mathrm{K}\right) \quad(\mathrm{A} 18)$

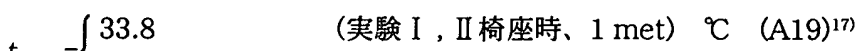
$t_{\text {sksw }}=\left\{\begin{array}{llll}33.8 & \text { (実験 IIIエルコメータ、2.8 met) }{ }^{\circ} \mathrm{C} & (\mathrm{A} 20)^{21)} \\ 31.8\end{array}\right.$

$t_{\text {op }}=\left(h_{c} t_{a}+h_{\text {rop }} t_{\text {rop }}\right) /\left(h_{c}+h_{\text {rop }}\right) \quad{ }^{\circ} \mathrm{C} \quad(\mathrm{A} 21)^{29)}$

$h_{\text {rop }}=4 \varepsilon \sigma\left\{273.2+\left(t_{a}+t_{\text {rop }}\right) / 2\right\}^{3} \cdot f_{\text {eff }} \quad \mathrm{W} /\left(\mathrm{m}^{2} \cdot \mathrm{K}\right) \quad(\mathrm{A} 22)$

APPENDIX II :

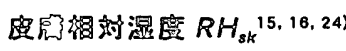

皮局相対湿度 $R H_{s k}$ は皮虎に接する空気の水蒸気圧 $p_{s k s f}$ と平均皮温 における飽和水蒸気圧 $p_{s k}$ の関倸によって次式で定義される。

$R H_{s k}=p_{s k s f} / p_{s k} \quad$ ND (A23)

一方、拡散蒸散と発汗によって人体皮虞表面からの蒸発密度 $q_{w s k}$ は 
次のように示される。

$q_{w s k}=\left(p_{s k s f}-p_{a}\right) /\left(R_{w c l e}+R_{w s e}\right) \quad \mathrm{g} /\left(\mathrm{h} \cdot \mathrm{m}^{2}\right) \quad(\mathrm{A} 24)$

また、皮膚が完全に水で濡れた場合の皮膚表面からの最大蒸発密度 $q_{\text {wmax }}$ は次式で示される。

$q_{w \max }=\left(p_{s k}-p_{\mathrm{a}}\right) /\left(R_{\mathrm{wcle}}+R_{\mathrm{wse}}\right)$

$\mathrm{g} /\left(\mathrm{h} \cdot \mathrm{m}^{2}\right) \quad(\mathrm{A} 25)$

このとき、皮覤表面の濡れ率 $w$ は次のように示される。

$W=q_{\mathrm{wsk}} / q_{\mathrm{wmax}}$

ND (A26)

$=\left(p_{\text {sksf }}-p_{a}\right) /\left(p_{s k}-p_{a}\right)$

つまり、皮膚表面の水蒸気圧 $p_{s k s f}$ は皮膚表面の濡れ率 $w$ との関係 により次式で示される。

$p_{s k s f}=w p_{s k}+(1-w) p_{a}$ $\mathrm{kPa} \quad$ (A27)

よって、次に示す既存の皮膚相対湿度の関係式 ${ }^{15)}$ が導かれる。

$R H_{s k}=w+(1-w) p_{a} / p_{s k}$

ND (A28)

\section{記号の説明}

$a_{s k}$ : 平均皮温 $t_{s k}$ における飽和水蒸気圧 $P_{s k}$ に関わる係数 $P_{s k}=a_{s k} t_{s k}+b_{s k},\left(a_{s k}=0.270,27<t_{s k}<37{ }^{\circ} \mathrm{C}\right)$ $b_{s k}$ : 平均皮温 $t_{s k}$ における飽和水蒸気圧 $P_{s k}$ に関わる係数 $P_{s k}=a_{s k} t_{s k}+b_{s k},\left(b_{s k}=-3.83,27<t_{s k}<37{ }^{\circ} \mathrm{C}\right)$

$f_{c l}$ : 人体表面積増加率 (= 着衣表面積 / DuBois 面積 )

$f_{e f f}$ : 人体有効放射面積率

$h$ : 総合熱伝達率 $\left(=h_{c}+h_{r o p}\right)$

$h_{c}:$ 対流熱伝達率

$h_{r}:$ 放射熱伝達率 $\left.\left(=4 \varepsilon \sigma \sigma 273.2+\left(t_{a}+t_{\text {rop }}\right) / 2\right\}^{3}\right)$

$h_{\text {rop }}$ : 作用放射熱伝達率 $\left(=f_{\text {eff }} \cdot h_{r}\right)$

$i_{c l} \quad:$ 着衣の透湿効率

$k_{\text {dif }}$ : 拡散による蒸散熱透過率

$k_{L}$ : 潜熱変換係数 $\mathrm{g} / \mathrm{h} \rightarrow \mathrm{W}\left(=H_{L} / 3600=0.674\right)$

$k_{\text {Lres }}$ : 呼吸による潜熱流率

$k_{\max }:$ 濡れた皮膚表面からの蒸散熱透過率

$k_{\mathrm{rc}}$ : 放射と対流による熱透過率

$k_{\text {Sres }}:$ 呼吸による顕熱流率

$k_{\text {swt }}$ ：温熱性発汗による蒸散熱流率

$k_{\text {swe }}$ ：中立温感時の運動性発汗による蒸散熱流率

$H_{L}:$ 水の蒸発潜熱 $\left(=2.43 \times 10^{3}\right)$

$L R$ : ルイス数 $\quad(=16.5)$

$p_{a}:$ 周囲空気の水蒸気圧

$p_{e x}:$ 呼気の水蒸気圧

$p_{s k}$ : 平均皮膚表面温度における飽和水蒸気圧

$p_{\text {sksf }}$ : 皮膚表面に接する空気の水蒸気圧

$q_{c}:$ 対流による熱流密度

$q_{d l f}:$ 拡散蒸散による熱流密度

$q_{\text {exw }}:$ 外部仕事率密度

$q_{\text {Lres }}:$ 呼吸による蒸発熱流密度

$q_{\max }$ : 濡れた人体表面からの最大蒸発熱流密度

$q_{M}:$ 代謝熱流密度

$q_{r}:$ 放射による熱流密度

$q_{\text {Sres }}:$ 呼吸による䫓熱流密度

$q_{L s k}$ : 人体表面からの蒸散熱流密度 $\left(=q_{d l f}+q_{s w}\right)$

$q_{s w}$ : 発汗による蒸散熱流密度 $\left(=q_{s w e}+q_{s w l}\right)$
$\mathrm{W} /\left(\mathrm{m}^{2} \cdot \mathrm{kPa}\right)$

$\mathrm{W} /(\mathrm{g} / \mathrm{h})$

$\mathrm{W} /\left(\mathrm{m}^{2} \cdot \mathrm{kPa}\right)$

$\mathrm{W} /\left(\mathrm{m}^{2} \cdot \mathrm{kPa}\right)$

$\mathrm{W} /\left(\mathrm{m}^{2} \cdot \mathrm{K}\right)$

$\mathrm{W} /\left(\mathrm{m}^{2} \cdot \mathrm{K}\right)$

$\mathrm{W} /\left(\mathrm{m}^{2} \cdot \mathrm{K}\right)$

$\mathrm{W} /\left(\mathrm{m}^{2} \cdot \mathrm{K}\right)$

$\mathrm{J} / \mathrm{g}$

$\mathrm{K} / \mathrm{kPa}$

$\mathrm{kPa}$

$\mathrm{kPa}$

$\mathrm{kPa}$

$\mathrm{kPa}$

$\mathrm{W} / \mathrm{m}^{2}$

$\mathrm{W} / \mathrm{m}^{2}$

$\mathrm{W} / \mathrm{m}^{2}$

$\mathrm{W} / \mathrm{m}^{2}$

$\mathrm{W} / \mathrm{m}^{2}$

$\mathrm{W} / \mathrm{m}^{2}$

$\mathrm{W} / \mathrm{m}^{2}$

$\mathrm{W} / \mathrm{m}^{2}$

$\mathrm{W} / \mathrm{m}^{2}$

$\mathrm{W} / \mathrm{m}^{2}$ $q_{\text {swe }}$ : 中立温感時の運動性発汗による蒸散熱流密度

$\mathrm{W} / \mathrm{m}^{2}$

$q_{s w t}$ : 温熱性発汗による蒸散熱流密度

$q_{w b}$ : 人体からの水分流出による体重減少密度

$\mathrm{W} / \mathrm{m}^{2}$

$q_{w d l f}$ : 拡散蒸散による蒸発密度

$q_{w \max }$ : 濡れた人体表面からの最大蒸発密度

$q_{\text {wres }}$ : 呼吸による蒸発密度

$q_{\mathrm{wsk}}$ ：人体表面からの蒸発密度 $\left(=q_{\mathrm{wdlf}}+q_{\mathrm{wsw}}\right)$

$R_{c l}$ : 着衣熱抵抗 $\left(=0.155 I_{c l}\right)$

$R_{c l e}:$ 着衣の湿気抵抗

$R_{s}$ : 人体の表面熱伝達抵抗

$R_{s e}$ : 人体の表面湿気伝達抵抗

$R_{\text {wcle }}$ : 着衣の湿気抵抗

$R_{\text {wse }}$ : 人体の表面湿気伝達抵抗

$R H$ : 周囲空気の相対湿度

$R H_{s k}$ : 皮層表面に接する空気の相対湿度

$\mathrm{kPa} / \mathrm{K}$

$t_{a}:$ 室気温

$t_{e x}:$ 呼気温度

$\mathrm{kPa}$

$t_{o p}:$ 作用温度 $\left\{=\left(h_{\text {rop }} t_{\text {rop }}+h_{c} t_{a}\right) /\left(h_{r o p}+h_{c}\right)\right\}$

$t_{\text {rop }}:$ 作用放射温度

ND $\quad t_{s k}:$ 平均皮膚表面温度

ND $\quad t_{s k s w}$ : 温熱性発汗が始まる臨界平均皮唐表面温度

$\mathrm{W} /\left(\mathrm{m}^{2} \cdot \mathrm{K}\right) \quad V:$ 相対風速

$W:$ 皮層表面の濡れ率 $\left(=W_{d i f}+W_{s w}\right)$

$W_{d l f}:$ 拡散蒸散による濡れ率 $\left(=q_{d f f} / q_{\max }\right)$

$W_{s w}$ : 発汗による濡孔率 $\left(=q_{s w} / q_{\max }\right)$

$\eta$ : 外部機械仕事率 $\left(=q_{\mathrm{exW}} / q_{M}\right)$ $\mathrm{g} /\left(\mathrm{h} \cdot \mathrm{m}^{2}\right)$

$\mathrm{g} /\left(\mathrm{h} \cdot \mathrm{m}^{2}\right)$

$\mathrm{g} /\left(\mathrm{h} \cdot \mathrm{m}^{2}\right)$

$\mathrm{g} /\left(\mathrm{h} \cdot \mathrm{m}^{2}\right)$

$\mathrm{g} /\left(\mathrm{h} \cdot \mathrm{m}^{2}\right)$

$\left(\mathrm{K} \cdot \mathrm{m}^{2}\right) / \mathrm{W}$

$\left(\mathrm{kPa} \cdot \mathrm{m}^{2}\right) / \mathrm{W}$

$\left(\mathrm{K} \cdot \mathrm{m}^{2}\right) / \mathrm{W}$

$\left(\mathrm{kPa} \cdot \mathrm{m}^{2}\right) / \mathrm{W}$

$\left(\mathrm{kPa} \cdot \mathrm{m}^{2} \cdot \mathrm{h}\right) / \mathrm{g}$

$\left(\mathrm{kPa} \cdot \mathrm{m}^{2} \cdot \mathrm{h}\right) / \mathrm{g}$

ND

ND

${ }^{\circ} \mathrm{C}$

${ }^{\circ} \mathrm{C}$

${ }^{\circ} \mathrm{C}$

${ }^{\circ} \mathrm{C}$

${ }^{\circ} \mathrm{C}$

${ }^{\circ} \mathrm{C}$

$\mathrm{m} / \mathrm{s}$

ND

ND

ND

ND 